\title{
THE EVALUATION OF STUDENTS' PROSOCIAL BEHAVIOR ON PRIMARY EDUCATION LEVEL
}

\author{
Esti Setiawati, Ika Ernawati \\ PGRI University Yogyakarta, PGRI University Yogyakarta \\ E-mail: esti@upy.ac.id, ika@upy.ac.id
}

\begin{abstract}
This study aims to evaluate the prosocial behavior of elementary school level students, especially State Junior High School students in Bantul Regency. This research is evaluation research with a quantitative descriptive approach with the CIPP (Context, Input, Process, and Product) model. The research subjects were 131 students of Bantul Regency Public Middle School. Data collection through the questionnaire, interviews, observation, and documentation methods. The results of this study indicate that in general the prosocial behavior of students in Bantul Regency State Junior High Schools was included in the quite good category. The results of this study also showed that the strengthening of the prosocial behavior of state junior high school students in the Bantul Regency was good enough as outlined in the school development program planning document and school activity plan.
\end{abstract}

Keywords: evaluation, prosocial, primary education

\section{INTRODUCTION}

Education implementation is collective responsibility among family, school, and society. Each of three elements has a crucial role in order to implement its aim since the success of education implementation is collective success, and each party has a contribution to achieving the education aim.

Education is one of the bridges that educates the nation and has a very crucial role nation development. If the level of education is more developed and qualified, the nation will not be underestimated by others and have a huge opportunity to develop it in the broader space. Therefore, the broader and more in-depth education mastery by the societies is the more developed country is facing a more complex challenge.

Regarding the description, education can be seen from the perspectives of students, teachers, and parents in order to implement education in societies. The relationship between teachers and students should be a reciprocal relationship that needs each other. The relationship should be multi-direction because it is not only information delivery from teachers to students, but broader than that, including how both of them make the planned and designed education aim success. 
School is one of the formal education implementation foundations that gains trust from families or societies in building students' character. Besides academically sharpening knowledge, students also sharpen their humane kill, which is closely related to positive attitudes and behaviors towards people around them. These behaviors are closely related to students' prosocial behaviors that should be developed on primary education.

As social creatures, humans cannot be separated from other people who live in their surroundings because they are not only individuals but also social creatures who live and always interact with other individuals reciprocally. Humans need other people around them although their independence is very high. ${ }^{1}$

Students who are on Junior High School level are considered as in early adolescence age and have started building more extensive social interaction with other individuals in the family, social, or school environment. In the social interaction in the family environment, they interact with parents, relatives, or other members of the family every day on how to act, speak, cooperate, or respect each other. In the social environment, students do not only mingle and get along with their peers but people who are older than them. Indeed, if students want to get along with older individuals, they need high social skill in facing people around them. This social skill requires them to communicate and interact with their peers. Moreover, in the school environment, Junior High School students should interact with teachers, school principals, educational staff and other students.

School interaction requires high social skills in order to develop positive behaviors towards people around them. This high social skill will determine the success of communication with other people and the environment. One of the positive behaviors is prosocial. Prosocial is indicated with a desire to help other people without considering their interests. ${ }^{2}$ This prosocial behavior can be indicated with positive behaviors such as sharing, helping, sincere, charity, and others without expecting a return for themselves.

An experience that is obtained intensively in social interaction in the family environment will influence an individual's behavior regarding their social

\footnotetext{
${ }^{1}$ Zamzani Sabiq dan M. As'ad Djalali. "Kecerdasan Emosi, Kecerdasan Spiritual, dan Perilaku Prososial Santri Pondok Pesantren Nasyrul Ulum Pamekasan” Jurnal Psikologi Indonesia 1, no. 2 (2012): 53-65.

${ }^{2}$ Sarwono, S.W. Psikologi Sosial: Individu dan Teori-teori Psikologi Sosial. (Jakarta: Balai Pustaka, 2002), p. 328.
} 
intercommunication. ${ }^{3}$ It means that the attitudes which are shaped and develop within the family environment are brought to students' intercommunication environment. In other words, positive behavior can develop if higher social skills support it in order to build a relationship with teachers, school principals, educational staff, and other students. One of the ways to build the relationship is an excellent social skill in prosocial behavior with people around them. ${ }^{4}$

Prosocial behaviors are forms of behavior that emerge as a result of individuals who perform an interaction with other people so that prosocial behaviors are done to help other people without considering their condition. Almost all the acts of helping are encouraged by self-interest without expecting a return for themselves. This action demands a high sacrifice from an individual who is done voluntarily without expecting a return in any form from people who are helped.

Prosocial behavior is an act of helping other people to assist to other people without expecting a return for themselves. This condition will be hardly found in our social environment, moreover at present. ${ }^{5}$ Not a few people assist others because they want to be given a compliment. It cannot be defined people are no longer assist sincerely without a guaranteed return because, in reality, there are people who are willing to help sincerely. ${ }^{6}$

Therefore in the Curriculum 2013, positive behavior indicators on each lesson that are aimed to shape the character building of students at school are developed. The positive values in developing behaviors are given a lesson that is comprehensively given to all students on grade VII to IX. The development of positive behavior, especially prosocial behavior, is expected to develop well in the school environment so that it will support the students to carry out school tasks optimally.

Schools are required to be pioneers of developing students' character education. In the process of character development, prosocial behavior is one of the merit values that should and requires to be developed. Prosocial behavior is described as the behavior that

\footnotetext{
${ }^{3}$ Gerungan. Psikologi Sosial. (Bandung: Refika Aditama, 2004), p. 195.

${ }^{4}$ Michelson., Sugai, et.al. Social Skill Assesment and Training With Children. (New York: Plenum Press, 1985), p. 41.

${ }^{5}$ Rina Trifiana, "Pengaruh Kematangan emosi Terhadap Perilaku Prososial Remaja Pengguna Gadget di SMP Negeri 2 Yogyakarta” E-Journal Bimbingan dan Konseling Edisi ke-10 Tahun ke-4 (2015): 2 .

${ }^{6}$ Ibid.
} 
can provide other people with profit. It is marked by sharing, creating comfort for other people, giving goodness, or in the form of money, which is performed voluntarily and helping other people. ${ }^{7}$ While Dalton et al, stated that all studies which involve prosocial behavior as a result or predictor had indicated a positive connection with expected academic or social such as literacy understanding, study completion, friendship, peer acceptance, and relationship status with the work. ${ }^{8}$

Some result of research which reveals prosocial behavior has proven that it is developed because of some existing supporting factor and affects positive students' behaviors. For example, Rina Trifiana's research proved that the emotional maturity factor influences students' prosocial behavior, $10.4 \%$ towards prosocial behavior, while other factors influence $86.6 \%{ }^{9}$

The other research which reveals prosocial behavior is Noorwindhi et all's research on the effect of scouting extracurricular activities towards teenagers' prosocial behaviors in Junior High School stated that scouting activities could develop prosocial behavior. ${ }^{10}$ The development of prosocial behavior as the result of joining scouting activity is assumed that this activity will enrich spiritual learning and prosocial behavior experience, which are packaged in the form of fun learning and role model of prosocial behavior.

Similar to the previous research, Gusti Yuli Asih's et al. research on prosocial behavior is observed from empathy and emotional maturity. ${ }^{11}$ The result indicates that the prosocial behavior between man and women are not far different or almost the same because in a certain thing, women can easily assist, however in another occasion, men react faster to assist. Zamani Sabiq's, et.al. research also states that there is a positive relationship between emotional and spiritual intelligence towards prosocial behavior. ${ }^{12}$

\footnotetext{
${ }^{7}$ Carlo, G. Laura, M. And Walker, P. Prosocial Development: A Multidimensional Approach. (New York: Oxford University Press, 2014).

${ }^{8}$ Dalton, BW., Rosen, JA., Glennie, EJ., Lennon, J.M. and Bozck, R.N. Noncognitif Skiils in The Classroom: New Perspective on Educational Research. (NC: RTI Press, 2010).

${ }^{9}$ Rina Trifiana, "Pengaruh Kematangan emosi Terhadap Perilaku Prososial Remaja Pengguna Gadget di SMP Negeri 2 Yogyakarta” E-Journal Bimbingan dan Konseling Edisi ke-10 Tahun ke-4 (2015).

${ }^{10}$ Noorwindi K.,S., et.al. "Pengaruh Kegiatan Ekstrakurikuler Kepramukaan Terhada Perilaku Prososial Remaja di SMP Santa Ursula Jakarta” Persona: Jurnal Psikologi Indonesia 3, no. 3 (2014): 253268.

${ }^{11}$ Gusti Yuli Asih dan Margaretha Maria Sinta. "Perilaku Prososial Ditinjau dari Empati dan Kematangan Emosi” Jurnal Psikologi 1, no. 1 (2010): 33-42.

${ }^{12}$ Zamzani Sabiq dan M. As'ad Djalali. “Kecerdasan Emosi, Kecerdasan Spiritual, dan Perilaku Prososial Santri Pondok Pesantren Nasyrul Ulum Pamekasan” Jurnal Psikologi Indonesia 1, no. 2 (2012): 53-65.
} 


\section{Esti Setiawati, Ika Ernawati}

The more increasing an individual's emotional intelligence, the more increasing prosocial behavior is. Besides, the more increasing spiritual intelligence, the more increasing prosocial behavior is. Emotional and spiritual intelligence collectively provide a useful contribution, which is $55.1 \%$ towards prosocial behavior.

Regarding the research, Elisa Megawati's research also proved that prosocial behavior is closely related to psychological wellbeing on teenagers, which is indicated with the determinant coefficient score, which is 0.372 that indicates prosocial behavior towards psychological wellbeing is 37.2 , while other factors influence the other $62.7 \% .^{13}$

By looking at the elaboration and result of previous research, prosocial behavior becomes one of the urgent and compelling matters in the education world, especially in developing students' positive character at State Junior High School as the mandate of curriculum 2013. However, prosocial behavior has not been evaluated comprehensively and simultaneously for students of primary education. Based on the background, the researchers are encouraged to evaluate the prosocial behavior of students on primary education level, especially State Junior High School students.

\section{RESEARCH METHODS}

The methods were quantitative and qualitative descriptive methods. The research subjects were students of State Junior High School in Bantul Regency. The research samples were taken purposively, which were three State Junior High School in Bantul Regency (State 1 Junior High School Sedayu, State 1 Junior High School Sewon and State 3 Junior High School Kasihan) by considering various aspects such as demography and school culture aspects.

The data collection techniques which were utilized in this research were questionnaire, interview, observation, and documentation study. While the data analysis which was utilized was quantitative and qualitative descriptive analyses or using the mix of the quantitative and qualitative method to get comprehensive analysis of the research problem as explained by Borg. ${ }^{14}$

\footnotetext{
${ }^{13}$ Elisa Megawati. Hubungan Antara Perilaku Prososial dengan Psychological Well-Being pada Remaja. Universitas Udayana. Skripsi (Tidak Diterbitkan, 2015).

${ }^{14}$ Borg, W. And Gall, M. Educational Research: An Introduction 7th edition. (New York: Longman Inc, 2003).
} 
Meanwhile, in order to analyze how far the students' prosocial behavior evaluation result, which is in the form of quantitative data, the data was analyzed explanatory descriptively and analytically and presented in the form of percentage table. The data presented in the form of percentage was described, and the conclusion of each indicator based on the determined criteria is drawn. The percentage indicated information criteria that are revealed. The classification which was based on the mean ideal (Mi) and ideal Deviation Standard (Si) in the criteria which were determined based on the normal curve were adopted and modified from Glass \& Hopkins in Azwar ${ }^{15}$ whose formulation is:

$M i($ Mean ideal $)=1 / 2($ ideal maximum score + ideal maximum score $)$

$\mathrm{Si}($ Standar Ideal Deviation $)=1 / 6$ (Ideal maximum score - ideal minimum score); $\mathrm{X}=$ Empirical Score.

Based on the adoption and adaptation of formulation, scoring criteria is elaborated as follows:

Table 1.

Criteria of Prosocial Behavior Scoring

\begin{tabular}{cll}
\hline No. & \multicolumn{1}{c}{ Score Range } & \multicolumn{1}{c}{ Category } \\
\hline 1. & $\mathrm{Mi}+1,5 \mathrm{Si}<\mathrm{X} \leq \mathrm{Mi}+3 \mathrm{Si}$ & Excellent \\
\hline 2. & $\mathrm{Mi}+\mathrm{Si}<\mathrm{X} \leq \mathrm{Mi}+1,5 \mathrm{Si}$ & Good \\
\hline 3. & $\mathrm{Mi}-0,5 \mathrm{Si}<\mathrm{X} \leq \mathrm{Mi}+\mathrm{Si}$ & Fair \\
\hline 4. & $\mathrm{Mi}-1,5 \mathrm{Si}<\mathrm{X} \leq \mathrm{Mi}-0,5 \mathrm{Si}$ & Poor \\
\hline 5. & $\mathrm{Mi}-3 \mathrm{Si} \leq \mathrm{X} \leq \mathrm{Mi}-1,5 \mathrm{Si}$ & $\mathrm{Bad}$ \\
\hline
\end{tabular}

Note :

$\begin{array}{ll}\mathrm{Mi} & : \text { Mean Ideal } \\ \mathrm{Si} & : \text { Ideal Deviation Standard }\end{array}$

While the qualitative data analysis in this research was carried out duringt he data collection and after the data collection in certain period. The qualitative data analysis had data characteristics such as verbal words, information material which was processed from data editing to presentation in brief. During the qualitative data analysis, some main steps which were done were data collection, reduction, presentation and concluding or

\footnotetext{
${ }^{15}$ Saifudin Azwar, Metode Penelitian, cet. III (Yogyakarta: Pustaka Pelajar, 2009), p. 108.
} 
verification. The evaluation flows suggested by Miles and Huberman ${ }^{16}$ can be drawn as follow:

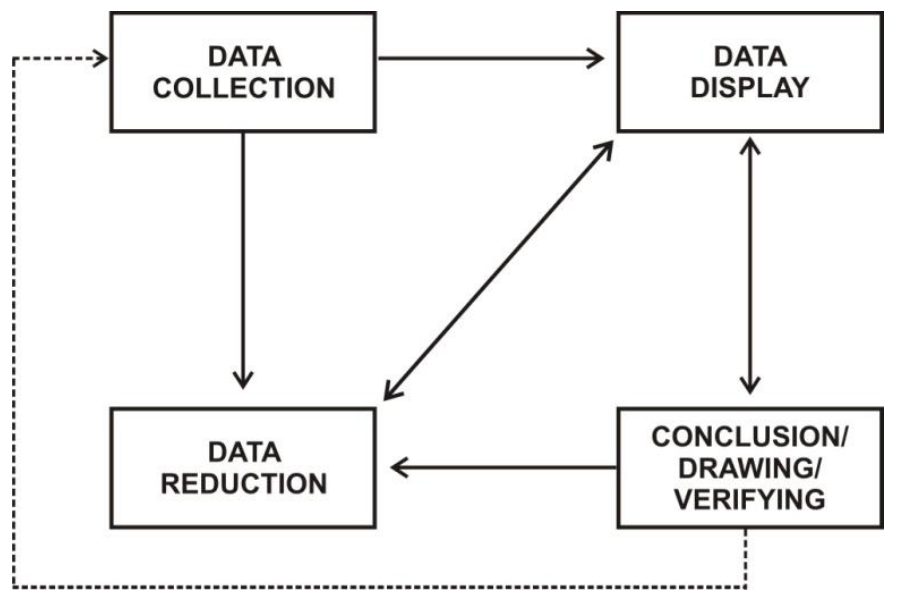

Figure 1.

Interactive Analysis Model of Miles and Huberman

\section{RESULT AND DISCUSSION}

The evaluation is carried out to find out how far prosocial behavior of State Junior Students in the Bantul Regency has reached all indicators. This evaluation activity is the continuance of evaluation instrument development of previous prosocial behavior that has been stated as valid and reliable so that it is relevant to be used for evaluating State Junior High School students in Bantul Regency.

The implementation of evaluation is performed simultaneously and accompanied by observation and interview with education stakeholders at school or some students who represent the populations. The evaluation activity is performed at three state schools with a total sample of 131 students who are distributed to the three schools. The result of the evaluation is elaborated in the following:

\section{Evaluation Result of Prosocial Behavior}

The data analysis results in this evaluation research indicate that the score of evaluation result moves between point 33 - 132 with a minimum score of 33 and a maximum of 132 . The ideal deviation standard from the research result is 16.5 , while the p. 23.

\footnotetext{
${ }^{16}$ Matthew B. Miles \& A. Michael Huberman, Analisis Data Kualitatif. (Jakarta: UI Press, 1992),
} 
mean ideal is 82.5 . Based on the data analysis result with the criteria that have been explained, the table can be presented as follows.

Table 2.

The Clasification of Prosocial Behavior Criteria

\begin{tabular}{lcc}
\hline \multicolumn{1}{c}{ Interval } & Score $(\mathbf{X})$ & Criteria \\
\hline $\mathrm{Mi}+1,5 \mathrm{Si}<\mathrm{X} \leq \mathrm{Mi}+3 \mathrm{Si}$ & $107,25<\mathrm{X} \leq 132$ & Excellent \\
\hline $\mathrm{Mi}+\mathrm{Si}<\mathrm{X} \leq \mathrm{Mi}+1,5 \mathrm{Si}$ & $99<\mathrm{X} \leq 107,25$ & Good \\
\hline $\mathrm{Mi}-0,5 \mathrm{Si}<\mathrm{X} \leq \mathrm{Mi}+\mathrm{Si}$ & $74,25<\mathrm{X} \leq 99$ & Fair \\
\hline $\mathrm{Mi}-1,5 \mathrm{Si}<\mathrm{X} \leq \mathrm{Mi}-0,5 \mathrm{Si}$ & $57,75<\mathrm{X} \leq 74,25$ & Poor \\
\hline $\mathrm{Mi}-3 \mathrm{Si} \leq \mathrm{X} \leq \mathrm{Mi}-1,5 \mathrm{Si}$ & $33<\mathrm{X} \leq 57,75$ & Bad \\
\hline
\end{tabular}

Based on the data analysis result with the criteria that have been elaborated, the percentage of prosocial behavior of State Junior High School students in Bantul Regency can be explained as follow: 1) $12.213 \%$ with excellent criteria, 2) $32.824 \%$ with suitable criteria, and 3) $54.961 \%$ with fair criteria. For more details, the data analysis result can be presented in the following table.

Table 3.

Classification of Percentage Result of Junior High School Students'

Behavior in Bantul Regency

\begin{tabular}{cccc}
\hline No. & Score & Data Number & Percentage (\%) \\
\hline 1. & $107.25-132$ & 16 & 12.213 \\
\hline 2. & $99-107.25$ & 43 & 32.824 \\
\hline 3. & $74.25-99$ & 72 & 54.961 \\
\hline 4. & $57.75-74.25$ & 0 & 0 \\
\hline 5. & $33-57.75$ & 0 & 0 \\
\hline
\end{tabular}

Based on the analysis data, it indicates that the highest percentage in prosocial behavior of State JHS students in Bantul Regency is a score from 74.25 to 99 with a percentage of $54.961 \%$. It indicates that in general, the prosocial behavior of State JHS students in the Bantul Regency is categorized as fair. For more detail, the description result of prosocial behavior analysis is presented in the following diagram. 


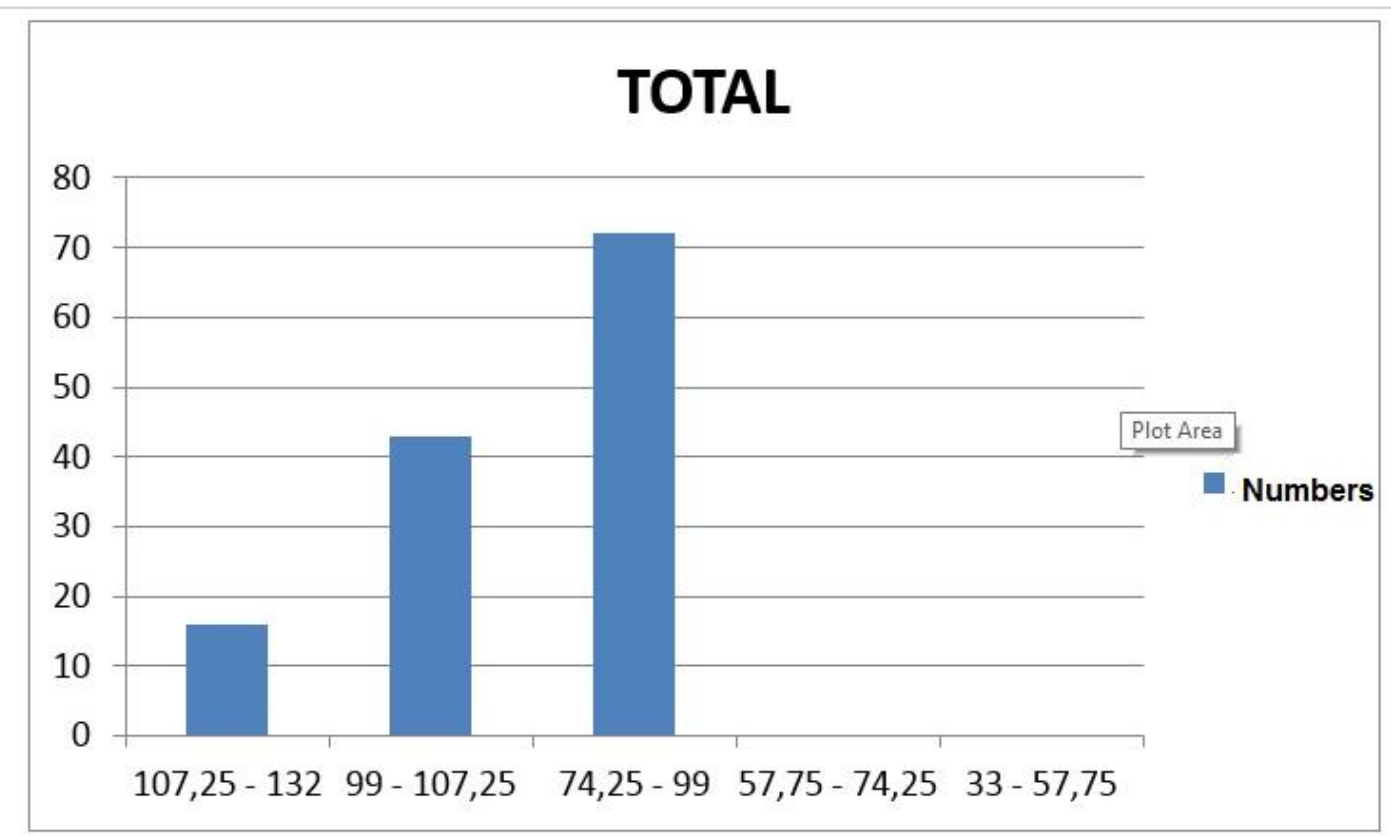

Figure2.

Percentage Diagram of Students' Prosocial Behavior

The previous bar chart indicates that the highest percentage in prosocial behavior of State JHS students in the Bantul Regency is on the third level, with a score range of 74.25 to 99 . However, the following percentage, which is on the score range of 99 to 107.25, also has a pretty high percentage, which is $32.824 \%$. Based on the analysis result, the percentage of State JHS students' prosocial behavior in the Bantul Regency is categorized as fair.

\section{Best Practice of State JHS Students' Prosocial Behavior Development in Bantul Regency}

Based on the result of observation, interview, or existing documentation, generally, prosocial behavior development has been implemented in an integrated manner in the learning process, extracurricular, or other school activities that involve students. If it is reviewed from the existing context, in general, the best practices on State JHS students' prosocial behavior in Bantul Regency have been categorized as fair. Best Practice of students' prosocial behavior development at each school, which is involved in the research, can be explained as follow. 
The implementation and effectiveness of students' prosocial behavior development at State 3 JHS Kasihan is pretty useful. Based on the interview with the school principals, school counselors, and some students, the development of prosocial behavior development through some activities both in the learning process and extracurricular activities can be implemented well because all parties support the implementation of superior students' character. The school principal directly coordinates with the assistance of some school counselors to provide coaching to students concerning prosocial behavior development. Based on the researchers' observation, the implementation and manifestation of prosocial behavior are no other than because the school wants to manifest and develop a merciful culture-based character education at school.

It also prevails on the development of State 1 JHS Sewon students' prosocial behavior. The school enacts a stringent regulation. All activities which involve students are monitored by the team, which is built by the school principal. This team cooperates as the procedures of students' prosocial behavior development that has been declared at school through learning, extracurricular, religious, flag ceremony, and self-development counseling activities. At State 1 JHS Sedayu, the learning process is carried out comprehensively by integrating cognitive, affective, and psychomotor learning processes. The initial process of learning is always initiated with a book reading movement for fifteen minutes and continued with the learning process. School literacy movement is emphasized because, by reading, students will learn to respect other people, tolerance, school societies, social attitudes, and cooperation. Teachers are assigned to guide during students' free reading. They also direct and encourage them to develop their selves optimally in the learning process. The positive attitude and skill in finding and initiating knowledge and develop science should be supported to make it grow optimally.

Mass community service activity is carried out by all school societies, school principals, teachers, students, and educational staff at every beginning of the month or first week of the month after the flag ceremony. This activity is routinely performed monthly to fertilize cooperation, mutual help and respect, and tolerance attitudes. All school societies bring cleaning equipment. The coordinator is assigned to each classroom and place. The implementation is done in mass with the focus of each classroom and guided by the homeroom teacher. 
Considering the explanation, the best practice of prosocial behavior development has been implemented and included in learning, extracurricular, religious, or other activities followed by students.

\section{CONCLUSION}

Based on the descriptive quantitative and qualitative explanation and analysis, students' prosocial behaviors have been performed by students of State JHS in Bantul Regency during the learning process or extracurricular. In general, the percentage of State JHS students' prosocial behavior in the Bantul Regency is categorized as fair with the percentage which reaches $54.961 \%$, good category which reaches $32.824 \%$ and top category which reaches $12.213 \%$.

The development of prosocial behavior of State JHS students in the Bantul Regency has been performed comprehensively and simultaneously through the learning process, mandatory or selection extra-curricular, and religious activities at school. The development of students' prosocial behaviors at school is performed under the guidance and monitoring of school principals and teachers, including education staff.

\section{REFERENCES}

Asih, Gusti Yuli \& Margaretha Maria Sinta. (2010). "Perilaku Prososial Ditinjau dari Empati dan Kematangan Emosi” Jurnal Psikologi 1, no. 1: 33-42.

Azwar, Saifudin. (2009). Metode Penelitian, cet. III (Yogyakarta: Pustaka Pelajar).

BW., Dalton. et.al. (2010). Noncognitif Skiils in The Classroom: New Perspective on Educational Research. (NC: RTI Press).

Gerungan. (2004). Psikologi Sosial. (Bandung: Refika Aditama).

K.,S., Noorwindi, et.al. (2014). "Pengaruh Kegiatan Ekstrakurikuler Kepramukaan Terhada Perilaku Prososial Remaja di SMP Santa Ursula Jakarta" Persona: Jurnal Psikologi Indonesia 3, no. 3: 253-268.

Laura, Carlo, G. et.al. (2014). Prosocial Development: A Multidimensional Approach. (New York: Oxford University Press).

Megawati, Elisa. (2015). Hubungan Antara Perilaku Prososial dengan Psychological Well-Being pada Remaja. Universitas Udayana. Skripsi (Tidak Diterbitkan). 
Miles, Matthew B. \& A. Michael Huberman. (1992). Analisis Data Kualitatif. (Jakarta: UI Press).

Sabiq, Zamzani \& M. As'ad Djalali. (2012). "Kecerdasan Emosi, Kecerdasan Spiritual, dan Perilaku Prososial Santri Pondok Pesantren Nasyrul Ulum Pamekasan” Jurnal Psikologi Indonesia 1, no. 2: 53-65.

Sugai, Michelson, et.al. (1985). Social Skill Assesment and Training With Children. (New York: Plenum Press).

S.W., Sarwono. (2002). Psikologi Sosial: Individu dan Teori-teori Psikologi Sosial. (Jakarta: Balai Pustaka).

Trifiana, Rina. (2015). "Pengaruh Kematangan emosi Terhadap Perilaku Prososial Remaja Pengguna Gadget di SMP Negeri 2 Yogyakarta" E-Journal Bimbingan dan Konseling Edisi ke-10 Tahun ke-4.

W., Borg \& Gall, M. (2003). Educational Research: An Introduction 7th edition. (New York: Longman Inc). 